\title{
PENINGKATAN KUALITAS PENYUSUNAN LAPORAN KEUANGAN MANUAL MENJADI DIGITALISASI AKUNTANSI SEDERHANA PADA PELAKU UMKM DI KABUPATEN SERANG
}

\author{
Ayunita Ajengtiyas Saputri Mashuri ${ }^{1}$ dan Husnah Nur Laela Ermaya ${ }^{2}$ \\ ${ }^{1}$ Fakultas Ekonomi dan Bisnis, UPN Veteran Jakarta \\ Email : ayunita.ajeng@upnvj.ac.id \\ ${ }^{2}$ Fakultas Ekonomi dan Bisnis, UPN Veteran Jakarta \\ Email : husnah_ermaya@upnvj.ac.id
}

\begin{abstract}
The results of observations made in the field show that, both manual and computerized accounting records cannot be applied properly to MSME players due to the absence of sufficient human resources to support the implementation of digitalized accounting both using mobile gadgets and computerized accounting. This expertise is needed to increase the skills of MSME entrepreneurs in developing their respective businesses. Therefore, this service is focused on training MSME players for training on digitizing accounting using accounting application software (SiApik and Zahir Simply) in Serang Regency. The stages carried out in the following abdimas activities are: 1) providing scientific training on accounting both manual and SiApik and Zahir Simply to prospective SMEs, 2) provide teaching to MSME actors knowledge and skills in the field of accounting, 3) carry out continuous monitoring and assistance to prospective MSME actors so that the accounting learning process, both manual and zahir accounting, can run well in the environment of MSME actors in Serang Region. The number of participants is 23 people. This community service activities have been carried out well through Webinar using Google Meet media and have been have been held on two days, 18 to 19 July 2020.
\end{abstract}

Keywords: Digitalization, Accounting, UMKM, Serang Region

\begin{abstract}
ABSTRAK
Dalam hasil observasi yang dilakukan di lapangan menunjukkan bahwa, pencatatan akuntansi baik secara manual maupun komputerisasi masih belum dapat diterapkan dengan baik pada para pelaku UMKM dikarenakan tidak adanya sumber daya manusia yang cukup mendukung dalam implementasi penerapan akuntansi secara digitalisasi baik dengan menggunakan gadget mobile dan komputerisasi akuntansi. Keahlian ini sangat diperlukan untuk menambah keterampilan para pelaku usaha UMKM dalam mengembangkan usaha masing-masing para pelaku usaha. Oleh karena itu kegiatan pengabdian difokuskan pada pelatihan para pelaku UMKM untuk pelatihan digitalisasi akuntansi dengan menggunakan software aplikasi akuntansi (SiApik dan Zahir Simply) di Kabupaten Serang. Tahapan-tahapan yang dilakukan dalam kegiatan abdimas berikut adalah: 1) memberikan pelatihan keilmuan tentang akuntansi baik manual maupun SiApik dan Zahir Simply kepada para calon pelaku UMKM, 2) memberikan pengajaran terhadap para pelaku UMKM pengetahuan dan ketrampilan dalam bidang Akuntansi, 3) melakukan pemantauan dan pendampingan yang berkesinambungan terhadap para calon pelaku UMKM hingga proses pembelajaran akuntansi baik secara manual maupun zahir accounting dapat berjalan dengan baik di lingkungan pelaku UMKM di Kabupaten Serang. Jumlah peserta adalah sebanyak 23 orang. Kegiatan pengabdian masyarakat telah terlaksana dengan baik melalui Webinar dengan menggunakan media Google Meet dan telah dilaksanakan hanya dalam 2 hari yaitu pada tanggal 18 dan 19 Juli 2020.
\end{abstract}

Kata Kunci: Digitalisasi, Akuntansi, UMKM, Kabupaten Serang

\section{PENDAHULUAN}

\subsection{Analisis Situasi}

Dalam perspektif dunia saat ini, berwirausaha menjadi salah satu alternatif sebagai bentuk mata pencaharian. Salah satunya adalah usaha mikro, kecil dan menengah (UMKM). Pemerintah Indonesia menyadari bahwa UMKM memiliki peranan dalam pertumbuhan dan pembangunan perekonomian negara berkembang maupun negara maju. Didalam perkembangannya UMKM sejalan dengan penyerapan jumlah tenaga kerja, karena kalangan menengah kebawah cukup memenuhi kriteria syarat para pencari pekerja terutama para pengusaha UMKM. Selain dari penyerapan jumlah tenaga kerja UMKM turut memiliki pengaruh dalam pertumbuhan Produk Domestik Bruto (PDB). Negara memahami pengertian PDB sebagai satuan ukur makro ekonomi pada produksi barang dan jasa dalam waktu yang telah ditentukan capaian pada suatu negara. PDB 
adalah bentuk refleksi kemampuan ekonomi suatu negara, dimana negara-negara yang bergabung pada G20 menyadari bahwa Indonesia merupakan salah satu negara penghasil PDB terbesar di dunia dalam perkumpulan 20 negara tersebut.

Menurut data Statistik pada tahun 2009 menunjukkan UMKM merupakan salah satu jenis usaha yang dapat menyumbang jumlah PDB dengan porsi yang cukup signifikan. Hal tersebut dapat ditunjukkan dengan jumlah pertumbuhan Produk Domestik Bruto (PDB) di tahun 2009 yaitu dengan jumlah persentase 4,5\% dan meningkat secara simultan pada tahun 2017 menjadi 5,01, dilanjutkan peningkatan pada triwulan I tahun 2018 dengan jumlah persentase 5,06\%, data juga menunjukkan secara parsial PDB disumbangkan dengan jumlah 60,34\% dari UMKM. Dapat disimpulkan, dengan data yang terlampir tersebut menunjukkan bahwa UMKM penting peranannya dalam pembangunan serta pertumbuhan ekonomi Indonesia. Terdapat beberapa faktor yang dapat mempengaruhi pertumbuhan UMKM menjadi kuat dalam membangung perekonomian, yaitu diantaranya memiliki fleksibilitas yang besar. Pemerintah Indonesia memberikan dorongan dan dukungan untuk para pengusaha UMKM dalam menjalankan usahanya. Hal tersebut dijelaskan dalam UU Nomor 20 tahun 2008, yang menyebutkan bahwa pemberdayaan UMKM perlu diselenggarakan secara menyeluruh, optimal dan berkesinambungan melalui perkembangan iklim yang kondusif, pemberian kesempatan berusaha, dukungan dan perlindungan dan memberikan pengembangan usaha seluas-luasnya, sehingga menjadi keunggulan UMKM untuk dapat memiliki kemampuan fokus dalam menjalankan usaha, memiliki fleksibilitas nasional, biaya yang rendah dan kecepatan inovasi.

Dari sekian banyak permasalahan UMKM yang terjadi di Indonesia, permasalahan yang sering ditemui adalah soal modal, urusan perizinan, rendahnya kesadaran untuk membayar pajak, kurangnya inovasi, banyaknya pelaku UMKM yang masih gagap teknologi. Perkembangan teknologi mendorong ekonomi digital yang bermanfaat bagi pelaku UMKM.Manfaat dalam memasarkan produknya dan kemudahan proses produktivitas para pelaku UMKM. Kehadiran saluran marketplace dan media sosial membuka peluang bagi pelaku UMKM dalam mengenalkan produk mereka. Selain itu, produktivitas pelaku UMKM semakin mudah dan efisien berkat adanya perkembangan teknologi, mulai dari melakukan pembukuan secara digital, membayar pajak melalui sistem aplikasi, dan lain-lain. UMKM membutuhkan dukungan dalam hal permodalan dan pemberian bantuan dalam hal pemasaran dan fasilitas usaha dari Pemerintahan Indonesia. Berdasarkan data Depkop.go.id menyebutkan bahwa tingkat perkembangan ekspor UMKM tahun 2016-2017 hanya menghasilkan sebesar 18,58\%, hal tersebut menunjukkan bahwa UMKM masih tertinggal jauh dibandingkan dengan produk impor barang dari luar negeri yang masuk ke Indonesia dengan harga yang jauh lebih murah dari produk-produk dalam negeri. Sehingga perlunya dukungan dan keberpihakan pemerintah Indonesia untuk dapat mendukung kegiatan UMKM. Hal tersebut seperti yang disampaikan oleh kepala bidang Usaha Mikro Dinas Koperasi Kota Perindustrian dan Perdagangan Pemerintah Kabupaten Serang oleh ibu Dra Vita Agustini, M.A dalam diskusi yang kami lakukan pada 20 Februari 2020 di kantor beliau untuk mendiskusikan permasalahan-permasalahan yang terjadi pada para pelaku UMKM di kota Serang. Kendala utama UMKM saat ini adalah akses ke lembaga keuangan dan pasar. Hal tersebut seperti yang dijelaskan dalam penelitian Adiningsih (2001), UMKM memiliki kontribusi yang cukup baik dalam perekonomian nasional, tetapi nyatanya di balik kontribusi tersebut, UMKM memiliki segudang permasalahan yang mendasar, yaitu lemahnya kemampuan dalam usaha, kualitas Sumber daya manusia yang masih terbatas serta lemahnya akses ke Lembaga keuangan khususnya di Lembaga keuangan perbankan. Didukung oleh penelitian Urata (2000), permasalahan utama UMKM adalah mayoritas UMKM belum Bankable, baik disebabkan oleh belum adanya 
manajemen keuangan yang transparan maupun kurangnya kemampuan dalam finansial dan manajerial.

Faktanya, Masih banyak para pelaku UMKM yang belum menyadari pencatatan keuangan dan pembukuan yang terorganisir dengan baik itu penting. Pelaku UMKM harus bisa memisahkan antara fungsi manajerial, fungsi operasional dan fungsi manajemen sumber daya manusia. Ketika pelaku usaha mikro berkembang dan harus dikelola secara profesional maka pelaku usaha sudah siap dengan konsep manajemen modern tersebut. Sehingga para pelaku usaha tidak bisa mengidentifikasikan kondisi usahanya apakah dalam keadaan baik atau tidak. Bahkan di Era digital 4.0 saat ini, para pelaku usaha masih belum bisa memanfaatkan kecanggihan digital 4.0 tersebut dalam bidang Akuntansi. Sepertinya para pelaku UMKM di Indonesia belum menyadari pentingnya untuk memulai menggunakan teknologi informasi dalam pengelolah data keuangan. Mereka memiliki anggapan bahwa teknologi dalam akuntansi hanya mempersulit mereka dalam pencatatan keuangan, dan sebagian besar dari pelaku usaha belum melek dalam teknologi. Sehingga masih banyak dari para pelaku yang belum memanfaatkan teknologi dalam mengelolah data keuangan dalam kegiatan bisnis mereka. Akibatnya wajar jika beberapa di antara para pelaku usaha memiliki kesulitan dapat mempersiapkan laporan keuangan untuk dapat mengembangkan usaha mereka dalam hal permodalan.

Kelemahan dan kekurangan yang menjadi hambatan pada industri kecil, menengah perlu dicari akar permasalahannya sehingga dapat diatas baik oleh pemerintah Indonesia maupun para ikatan pengusaha, sebagai langkah upaya untuk mengembangkan usaha industri kecil dan menengah tersebut. Maka, diperlukan peranan Perguruan tinggi Negeri yang merupakan Lembaga Pendidikan yang memiliki kontribusi dalam mengembangkan Sumber Daya Manusia dapat ikut serta meningkatkan kesejahteraan masyarakat di sekitar dan turut serta melakukan pendampingan, membuat perencanaan serta merealisasikan pelaksanaan kegiatan dalam rangka pengabdian pada masyarakat. Harapannya para pengusaha UMKM mampu melakukan pengembangan dan menambah wawasan pengetahuan setelah dilaksanakannya pendampingan tersebut. Selain itu juga pendampingan dapat memberikan motivasi untuk para pelaku usaha dalam melaksanakan usahanya secara kompeten dan profesional.

Kondisi tersebut mendukung dengan diadakan pendampingan kepada masyarakat terutama kalangan pengusaha UMKM, sehingga kami selaku para Dosen Fakultas Ekonomi dan Bisnis UPN Veteran Jakarta memiliki inisiatif untuk memberikan kontribusi dalam rangka meningkatkan kesejahteraan masyarakat di sekitar dengan memberikan fasilitas pendampingan, memberikan perencanaan dalam pelaksanaan kegiatan pengabdian masyarakat. Sehingga dengan harapan UMKM mampu mengembangkan usahanya secara mandiri dan memberikan motivasi untuk bisa menjalankan usahanya dengan lebih baik.

\subsection{Permasalahan Mitra}

Provinsi Banten terbagi menjadi 4 (empat) kabupaten dan 4 (empat) kotamadya. Berdasarkan Undang-undang Nomor 51 tahun 2008, kota Serang merupakan salah satu Kabupaten di Banten, memiliki jumlah para pengusaha yang bergerak dalam usaha Usaha Mikro Kecil dan Menengah (UMKM). Para pengusaha UMKM tersebut memiliki peran yang sangat penting dalam menunjang perekonomian Kabupaten Serang. Hal tersebut dengan ditunjukan jumlah pada tahun 2019 sebanyak 37,505 usaha, jumlah tersebut didominasi dari sektor kuliner. Kabupaten Serang telah memperoleh penghargaan Natamukti pada tahun 2019 dengan penghargaan sebagai iklim ekonomi UMKM terbaik dari Kementerian Koperasi dan Usaha Kecil Menengah Indonesia (Serangkab.go.id, 2019). 
Data dari Badan Pusat Statistik (2018), menunjukkan bahwa Kota Serang dikenal sebagai kota sejuta industri dan menjadi kota penyangga (bufferzone) bagi ibukota negara Republik Indonesia. Pada tahun 2018 jumlah penduduk Kabupaten Serang sebanyak 1.493.591 jiwa, dengan komposisi jumlah penduduk laki-laki sebanyak 757.089 jiwa (50.36 persen) dan perempuan sebanyak 736.502 jiwa (49.64 persen). Di sisi lain, sebanyak 1.186 .421 jiwa (72.13 persen) atau usia produktif masyarakat memiliki jumlah dua pertiga dari jumlah keseluruhan penduduk Kabupaten Serang. Perkembangan UMKM yang cukup baik di Kabupaten Serang juga menimbulkan beberapa kendala dalam meningkatkan daya saing produk di pasar. Salah satu kendala pelaku mitra UKM yaitu pemodalan. Hal tersebut dikarenakan mereka belum mengetahui pembuatan laporan keuangan yang bisa diberikan kepada kreditor perbankan sebagai salah satu pinjaman. Abidin dan Dharma (2015) menyebutkan beberapa permasalahan umum yang dihadapi oleh UMKM di Serang berasal dari faktor internal maupun eksternal. Dilihat dari segi faktor internal, Pertama, kurangnya permodalan. Pelaku usaha cenderung menggunakan dana sendiri dan itu terbatas. Serta sulitnya mengajukan Pinjaman dari Bank atau Lembaga Keuangan karena UMKM tidak memenuhi persyaratan teknis dan administratif yang diminta oleh bank. Kedua, Terbatasnya Sumber daya Manusia dalam segi pengetahuan dan keterampilan. Sehingga UMKM sulit berkembang melalui penciptaan inovasi dan kreasi produk. Ditambah lagi ketidak tertarikan beberapa pelaku usaha dalam mengikuti perkembangan dapat menjadi penghambat dalam meningkatkan kualitas dan daya saing produk. Salah satu kelemahan pengetahuan dan keterampilan yang menjadi penghambat adalah terkait dengan pengetahuan pengolahan dana dalam penyusunan laporan keuangan. Suhairi (2004) berpendapat bahwa kelemahan UMKM dalam penyusunan laporan keuangan disebabkan rendahnya pendidikan, kurangnya pemahaman terhadap Standar Akuntansi Keuangan (SAK), dan pelatihan penyusunan laporan keuangan. Selain itu, hasil penelitian ini sesuai dengan hasil penelitian yang dilakukan oleh Jati et al. (2009) bahwa dalam pelaksanaan pembukuan akuntansi untuk menyajikan laporan keuangan merupakan hal yang masih sulit bagi UMKM. Hal tersebut disebabkan karena adanya keterbatasan pengetahuan pembukuan dalam akuntansi sederhana, rumitnya proses dalam pencatatan akuntansi, dan anggapan bahwa untuk menyajikan laporan keuangan bukanlah hal yang krusial bagi UMKM. Padahal terdapat beberapa cara dan metode yang dapat mempermudahkan pencatatan akuntansi. Oleh sebab itulah diciptakannya berbagai macam alat bantu dalam bentuk sistem aplikasi untuk untuk pencatatan akuntansi baik itu sederhana maupun yang sesuai dengan standar akuntansi yang berlaku, dimana sistem tersebut dalam menyajikan pencatatan dalam bentuk jurnal akuntansi sampai dengan menyajikan laporan keuangan yang dapat bersinergi ke semua bagian dan kegiatan entitas dalam satu sistem database. keterbatasan pengetahuan dan pemahaman pencatatan akuntansi menyebabkan kegiatan usaha UMKM terhambat berkembang.

\subsection{Solusi yang Ditawarkan}

Melakukan Pendampingan dan Pelatihan peralihan pencatatan manual menjadi digitalisasi Akuntansi sederhana bagi para pelaku UMKM di Kabupaten Serang.

Laporan keuangan Akuntansi secara digitalisasi dapat memberikan kemudahan para pemilik usaha UMKM dalam memperoleh informasi serta data yang tersusun secara sistematis. Terdapat beberapa keuntungan para pemilik usaha UMKM jika dapat menyajikan serta menyediakan laporan keuangan. Salah satu keutamaannya adalah para pengusaha dapat memperhitungkan keuntungan yang diperoleh, mengetahui berapa tambahan modal yang dicapai, dan juga dapat mengetahui bagaimana keseimbangan hak dan kewajiban yang dimiliki. Dalam menyajikan laporan keuangan tersebut dapat membantu para pemilik UMKM untuk dapat melakukan pengambilan keputusan dalam mengembangkan usahanya dengan dasar pada kondisi konkret 
keuangan yang dilaporkan secara lengkap bukan hanya didasarkan pada asumsi semata. Diharapkan Laporan Keuangan dengan menggunakan digitalisasi menjadi fasilitator usaha kecil dan menengah untuk mempermudah penyajian informasi yang transparan dan akuntabel.

Peranan usaha sektor UMKM yang begitu penting, mengharapkan dunia pendidik tidak hanya berada pada aspek pengajaran, pembelajaran dan Pendidikan saja. Tetapi, juga bisa memberikan fasilitas untuk dapat menjalankan peranannya untuk membantu SDM dalam mengembangkan diri secara kompeten dalam melaksanakan manajemen dan menyajikan pelaporan keuangan UMKM. SAK ETAP menyebutkan terdapat beberapa jenis penyajian Laporan keuangan, yaitu terdiri dari Neraca, laporan laba rugi, laporan perubahan modal dan catatan laporan posisi keuangan. Namun prakteknya para pelaku UKM kesulitan membuat laporan keuangan secara lengkap, jika para UMKM membuat salah satu laporan keuangan, misalnya neraca atau laporan laba rugi saja sudah sangat membantu usaha mereka dengan memanfaatkan digitalisasi akuntansi.

\section{METODE PELAKSANAAN PKM}

\subsection{Prosedur Kerja/Langkah Kerja}

Dalam pelaksanaan pendampingan Pengabdian Masyarakat, terdapat beberapa mekanisme pelaksanaan dalam memberikan pelatihan pembuatan laporan keuangan dasar dengan metode digitalisasi kepada para UKM yang ada di Kabupaten Serang, sebagai berikut:

a. Pada tahap awal, melaksanakan pengambilan data, survey serta melakukan wawancara dengan kepala Dinas Koperasi Kabupaten Serang di bulan Februari dan diskusi terkait permasalahan yang ada dalam UKM yang dibina di Kabupaten Serang. Dari hasil survei dan wawancara tersebut informasi yang didapat adalah para UKM masih belum memiliki kapabilitas yang cukup memadai dalam pembuatan laporan keuangan secara manual. Hambatan tersebut yang menjadi faktor untuk mendapatkan pemodalan dari kreditor/ bank. Sehingga salah satu alternatif untuk mengatasi kesulitan pencatatan tersebut yaitu memberikan opsi penyajian laporan keuangan secara digitalisasi

b. Pada tahap pelaksanaan. Metode pelaksanaan kegiatan pengabdian kepada masyarakat ini berupa seminar dan pelatihan kepada pelaku usaha mikro kecil dan menengah yaitu UMKM wilayah Serang. Setelah menghadiri seminar dan diberi pelatihan, selanjutnya dilaksanakan pendampingan agar terselenggara pencatatan akuntansi sederhana bagi setiap peserta UMKM.

Tahap pelaksanaan pelatihan dilakukan 2 (dua) tahap, yaitu (1) pemberian pengetahuan mengenai penerapan akuntansi sederhana yang dapat digunakan bagi para pelaku UMKM, serta (2) memotivasi para pelaku usaha agar dapat menjalankan usahanya secara profesional dengan cara memberikan pelatihan penyajian laporan keuangan yang terkomputerisasi dengan menggunakan Software SiApik dan Zahir Simply.

Metode Pelatihan

Untuk melaksanakan kegiatan tersebut, digunakan beberapa metode, yaitu:

a. Metode Ceramah

Metode ini dipilih untuk memberikan penjelasan berupa pengenalan terhadap akuntansi serta pentingnya penerapan akuntansi dalam keberlangsungan kegiatan usaha.

b. Metode Tanya Jawab

Metode Tanya jawab sangat penting bagi para peserta pelatihan, baik disaat menerima penjelasan, serta saat mempraktekkannya. Metode ini memungkinkan pelaku bisnis UMKM menggali pengetahuan sebanyak-banyaknya tentang penerapan akuntansi dalam keberlangsungan kegiatan usaha yang dilakukan.

c. Metode Simulasi 
Metode ini sangat penting diberikan kepada peserta pelatihan untuk memberikan kesempatan mempraktekkan materi pelatihan. Harapannya. Peserta pelatihan dapat benarbenar melakukan pencatatan akuntansi sederhana dengan memanfaatkan kemudahan SiApik dan Zahir Simply dalam kegiatan usahanya.

\section{HASIL DAN PEMBAHASAN}

Pelaksanaan pengabdian masyarakat pada UMKM di Kabupaten Serang terlaksana pada tanggal 18 Juli 2020 yang dilakukan dengan menggunakan webinar melalui google meeting. Sebelum terselenggaranya webinar pengabdian masyarakat, salah satu tim telah berkunjung dan bertemu dengan kepala bidang usaha mikro yaitu ibu Drs. Vita Agustini., M.A. di Dinas Koperasi Perindustrian dan Perdagangan Pemerintah Kabupaten Serang. Beliau menjelaskan ada beberapa kendala yang dihadapi oleh pelaku UMKM dalam menjalankan kegiatan usahanya. Kendala yang dihadapi salah satunya adalah terkait dengan pencatatan keuangan. Banyak para pelaku usaha bermasalah dengan kegiatan pencatatan akuntansi yang masih dilakukan dengan konvensional, yaitu pencatatan dengan menggunakan buku kas. Sehingga para pelaku memiliki kecenderungan mengabaikan pencatatan manual tersebut, dikarenakan disibukkan dengan kegiatan usaha. Dan disatu sisi lain kurangnya Pendidikan dan pelatihan yang mudah dipahami oleh para pelaku. Belajar dari pengalaman kegiatan pengabdian masyarakat periode lalu, dari sini kami tim pengabdian masyarakat dari Fakultas Ekonomi dan Bisnis memberikan solusi untuk melakukan pendampingan dan pelatihan dalam menyusun laporan keuangan berbasis digitalisasi akuntansi yang cukup mudah dan simple yaitu dengan menggunakan software aplikasi berbasis android yaitu SiApik dan Zahir Simply.

Sebelumnya kegiatan Tri Dharma termasuk kegiatan pengabdian masyarakat terlaksana dengan terjun langsung kepada masyarakat dalam memberikan pendampingan, dan pemberdayaan kegiatan. Kegiatan Pengabdian Masyarakat telah berlangsung di tengah masa pandemic Covid 19, sehingga pelaksanaan kegiatan pengabdian masyarakat tidak menjadi penghalang bagi tim untuk mendampingi dan memberikan pelatihan terkait pencatatan akuntansi menjadi digitalisasi akuntansi. Acara ini berlangsung secara online dengan menggunakan aplikasi Google Meet, dan sebagian besar peserta sudah terbiasa dalam menggunakan aplikasi tersebut, sehingga jumlah peserta yang hadir adalah sekitar 23 dari 30 peserta yang terdaftar oleh kepala bidang usaha mikro Kabupaten Serang. Para peserta yang hadir digolongkan para pelaku UMKM menuju naik kelas, dimana rata-rata omset yang dihasilkan adalah sebesar lebih dari 50 juta dalam setahunnya.

Kegiatan Pengabdian kepada Masyarakat tidak hanya dalam bentuk pemaparan materi sekaligus pengenalan pentingnya pencatatan akuntansi, namun juga kegiatan ini melakukan pendampingan sampai dengan pemberdayaan para pelaku UMKM Kabupaten Serang dapat melakukan pencatatan akuntansi dengan mengubah pola pencatatannya dengan menggunakan metode digitalisasi akuntansi dengan memanfaatkan smartphone yang dimiliki oleh masing-masing para pelaku usaha. Dalam proses mempelajari pencatatan akuntansi keuangan akan dengan mudah dilakukan seiring meningkatnya kemampuan para pengusaha UMKM dalam penggunaan tingkat seluler berbasis android maupun IOS. Sehingga hal tersebut akan memiliki keuntungan tersendiri untuk bagi para pengusaha untuk dapat memanfaatkan aplikasi gratis yang disediakan oleh Bank Indonesia bekerjasama dengan Ikatan Akuntansi Indonesia (IAI), dimana aplikasi tersebut dimana dengan Si Apik. Aplikasi berikutnya yang diberikan secara gratis kepada pada pengusaha UMKM selama 1 tahun pemakaian awal adalah Zahir Simply. Aplikasi akuntansi tersebut dapat memberikan kemudahan para pelaku UMKM untuk dapat melakukan pencatatan transaksi kegiatan keuangan mereka. 
Terdapat beberapa masalah yang dihadapi oleh pelaku usaha UMKM dalam memanajemen pengelolaan keuangan usaha, diantaranya adalah keterbatasan pengetahuan SDM terkait dengan metode pencatatan akuntansi, kurangnya kemampuan dalam manajemen pencatatan transaksi uang yang masuk dan keluar yang tidak dapat disajikan dalam laporan keuangan. Selain permasalahan tersebut, terdapat juga kendala yang dihadapi oleh pelaku UMKM yaitu kurangnya informasi mengenai aplikasi-aplikasi pencatatan akuntansi yang dapat dioperasikan melalui smartphone. Sehingga, dari permasalahan yang diidentifikasikan sebelumnya, solusi yang dapat diberikan adalah dengan cara memanfaatkan Aplikasi Akuntansi berbasis Android maupun IOS. Sehingga dengan pendampingan dalam meningkatkan kemampuan pencatatan akuntansi secara digitalisasi smartphone, para pelaku UMKM dapat memperbaiki pengelolaan keuangan dan berkembang dalam bidang usahanya, melalui peningkatan modal yang dapat diajukan sebagai syarat mengajukan pinjam modal dengan memenuhi salah satu syarat mengajukan pinjaman yaitu dapat menyajikan laporan keuangan terkait dengan kegiatan usaha. Dari fenomena tersebut, maka alternative yang diberikan adalah:

1. Mengevaluasi kembali pencatatan transaksi keuangan yang selama ini dilakukan oleh para pelaku usaha.

2. Melakukan penyusunan kembali pencatatan transaksi keuangan sesuai dengan standar akuntansi yang berlaku. Dimulai dengan pencatatan sesuai dengan persamaan akuntansi, yaitu Asset sama dengan Liabilitas ditambah dengan Ekuitas.

3. Memberikan pelatihan mengenai pencatatan transaksi keuangan. Yaitu menjelaskan dasar istilah-istilah akuntansi.

4. Menjelaskan materi yang diperlukan dalam penyusunan laporan keuangan

5. Memberikan pelatihan sederhana untuk mengidentifikasikan jenis transaksi. Sehingga hasil akhirnya adalah para pelaku dapat menganalisa kegiatan operasional yang dapat digunakan untuk pencatatan akuntansi.

6. Memberikan pelatihan mengenai penggunaan aplikasi akuntansi Usaha Mikro Kecil dengan menggunakan aplikasi SiApik dan Zahir Simply.

Adapun keberhasilan pengabdian masyarakat saat ini yang diharapkan dalam bentuk Tabel 1.

\section{Tabel 1}

Indikator Keberhasilan

\begin{tabular}{|c|c|c|c|}
\hline Kegiatan & Materi & Indikator Keberhasilan & Ketercapaian \\
\hline $\begin{array}{l}\text { Pertama } \\
18 \text { Juli } 2020\end{array}$ & $\begin{array}{l}\text { Mensosialisasikan pencatatan } \\
\text { akuntansi dan memberikan } \\
\text { penjelasan mengenai pemisahan } \\
\text { keuangan yang berkaitan antara } \\
\text { keuangan yang berasal dari kegiatan } \\
\text { usaha dan keuangan yang } \\
\text { menyangkut kepentingan pribadi. }\end{array}$ & $\begin{array}{lr}\text { Para Audiens } & \text { UMKM di } \\
\text { Kabupaten } & \text { Serang mulai } \\
\text { mengerti } & \text { pentingnya } \\
\text { memisahkan } & \text { keuangan } \\
\text { usaha dengan } & \text { keuangan } \\
\text { pribadi } & \end{array}$ & $\begin{array}{l}\text { Nilai rata-rata adalah } 50 \\
\% \text { dalam pelaksanaan } \\
\text { kegiatan }\end{array}$ \\
\hline $\begin{array}{l}\text { Kedua } \\
18 \text { Juli } 2020\end{array}$ & $\begin{array}{l}\text { Melakukan pendampingan serta } \\
\text { pelatihan penyusunan laporan } \\
\text { keuangan sederhana dengan bantuan } \\
\text { aplikasi SiApik dan Zahir Simply. }\end{array}$ & $\begin{array}{l}\text { Dalam prosesnya para } \\
\text { Peserta UMKM mulai } \\
\text { mampu membuat Laporan } \\
\text { Keuangan dengan media } \\
\text { Smartphone }\end{array}$ & 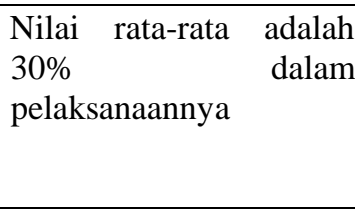 \\
\hline $\begin{array}{l}\text { Ketiga, } \\
19 \text { Juli } 2020\end{array}$ & $\begin{array}{l}\text { Melanjutkan pendampingan serta } \\
\text { pelatihan pembuatan laporan laba } \\
\text { rugi dengan menggunakan si Apik } \\
\text { dan zahir simply dengan } \\
\text { menggunakan handphone baik } \\
\text { android ataupun IOS }\end{array}$ & $\begin{array}{l}\text { Secara bertahap para peserta } \\
\text { UMKM memiliki progress } \\
\text { dalam pembuatan laporan } \\
\text { laba rugi dengan aplikasi } \\
\text { SiApik dan Zahir Simply }\end{array}$ & $\begin{array}{l}\text { Nilai pencapaian akhir } \\
\text { rata-rata adalah } 60 \% \\
\text { dalam pelaksanaannya }\end{array}$ \\
\hline
\end{tabular}




\section{Gambar 1}

\section{Acara Pengabdian Masyarakat SiApik}

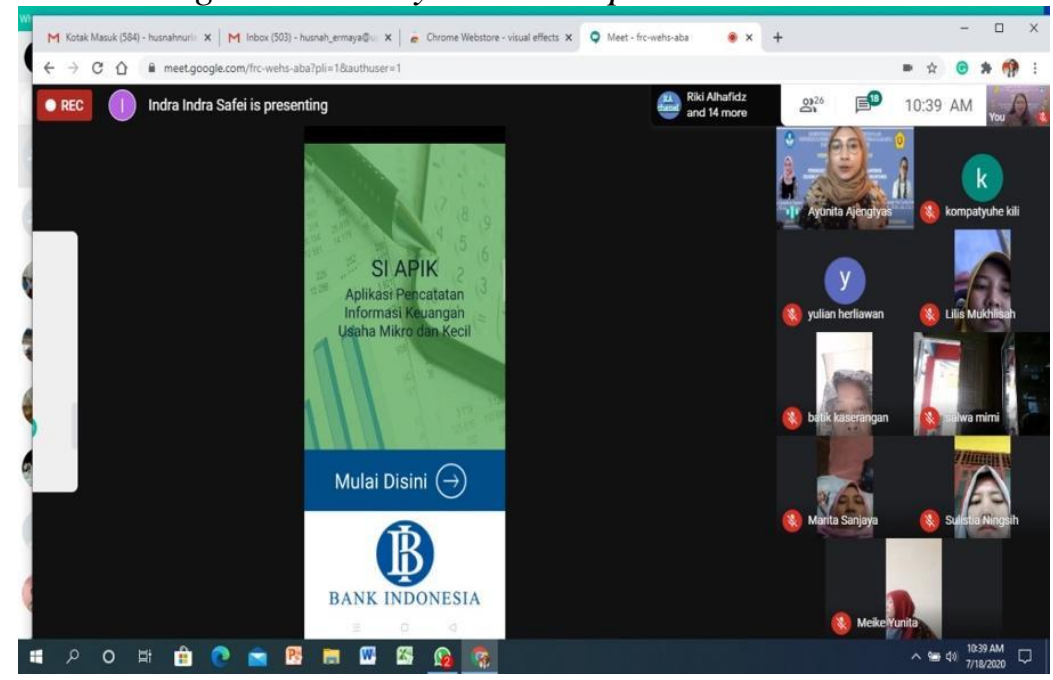

\section{Gambar 2}

Acara Pengabdian Masyarakat Zahir Simply
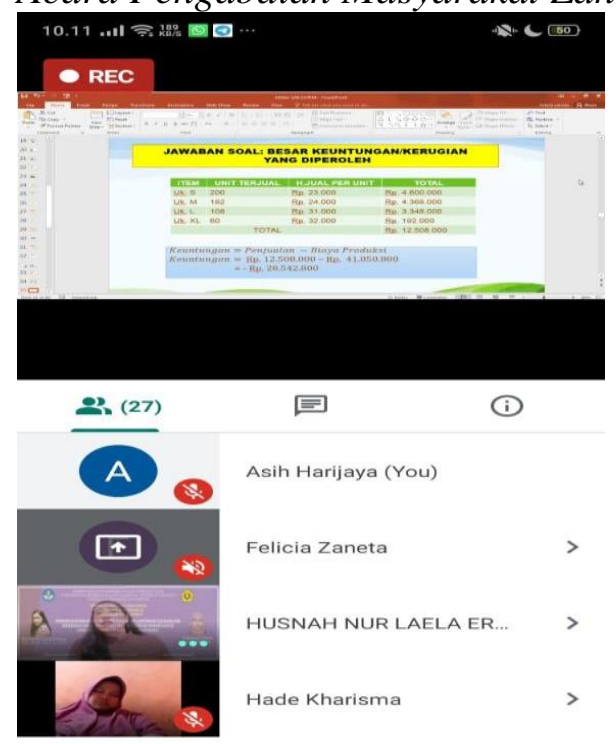

티

(i)

Also in the meeting (23)

\section{KESIMPULAN DAN SARAN}

\section{Kesimpulan}

Kegiatan pengabdian masyarakat telah dilaksanakan melalui Webinar dengan menggunakan media Google Meet dan telah dilaksanakan hanya dalam 2 hari yaitu pada tanggal 18 dan 19 Juli 2020, kesimpulan dari kegiatan yang dihasilkan selama pelaksanaan kegiatan ini adalah sebagai berikut:

1. Selama pelaksanaan kegiatan yang kami selenggarakan, para pelaku di Kabupaten Serang sangatlah antusias dalam mengikuti kegiatan yang kami berikan dan paparkan. Hal tersebut dapat terlihat walaupun acara Pengabdian Masyarakat sudah terselenggara, beberapa peserta masih menghubungi kami untuk bertanya tentang langkah-langkah pengoperasian. 
2. Para Peserta UMKM Kabupaten Serang telah mengikuti pelatihan pembuatan Laporan Keuangan sederhana yaitu laporan Neraca dan Laporan Laba Rugi dengan menggunakan aplikasi SiApik dan Zahir Simply yang bisa digunakan di Android atau IOS.

3. Tujuan dari kegiatan pengabdian ini adalah agar tercapainya para peserta UMKM Kabupaten Serang dalam memahami dan menyusun laporan keuangan sederhana dengan pemberdayaan implementasi akuntansi dasar bagi UMKM di Kabupaten Serang.

\section{Saran}

Jumlah para peserta UMKM sangat sedikit dari total jumlah yang turut bergabung yaitu 23 peserta. Menurut pengamatan yang dilakukan pada saat pelaksanaan, kemampuan para peserta perlu ditingkatkan lagi dan perlu adanya pelatihan lebih lama lagi. Karena adanya keterbatasan waktu dan media Online, hal tersebut akan menjadi resolusi instruktur untuk lebih memfokuskan diri dalam memberikan pelatihan lebih lanjut kepada para peserta UMKM.

Untuk kedepannya lagi, para peserta diminta untuk dapat hadir lebih banyak, dan kami para tim pengabdian masyarakat dapat terjun langsung berinteraksi dengan para pelaku UMKM setempat.

\section{Ucapan Terima Kasih (Acknowledgement)}

Tim Pengabdi Masyarakat mengucapkan banyak terimakasih kepada ketua Lembaga LPPM (Lembaga Penelitian dan Pengabdian Masyarakat) UPN Veteran Jakarta, Fakultas Ekonomi dan Bisnis UPNVJ, ibu Dra Vita Agustina, M.A selaku Kepala bidang Usaha Mikro di Dinas Koperasi Perindustrian dan Perdagangan Pemerintah Kabupaten Serang, serta ucapan terimakasih kepada para tim pendukung terlaksana pengabdian masyarakat dan peserta UMKM di kabupaten Serang yang berkenan mengikuti pendampingan dalam acara Pengabdian masyarakat UPNVJ.

\section{REFERENSI}

Undang-Undang Republik Indonesia Nomor 20 Tahun 2008 tentang Usaha Mikro, Kecil dan Menengah. (2008). Indonesia. https://peraturan.bpk.go.id/Home/Details/39653/uu-no-20tahun-2008

Wibowo, \& Arif, A. (2008). Akuntansi keuangan dasar 1 (3rd ed.). PT. Grasindo.

Belkaoui, A. R. (2011). Accounting theory: Buku 2 (5th ed.). Salemba Empat.

Hapsari, D. P., Andari, \& Hasanah, A. N. (2017). Model pembukuan sederhana bagi usaha mikro di Kecamatan Kramatwatu Kabupaten Serang. Jurnal Akuntansi, 22(2), 36-47. https://doi.org/10.30656/jak.v4i2.249

Putra, H. A., \& Kurniawati, E. P. (2012). Penyusunan laporan keuangan untuk usaha kecil dan menengah (UKM) berbasis standar akuntansi keuangan entitas tanpa akuntabilitas publik (SAK ETAP). Proceeding Call for Paper: Capturing Opportunities For ASEAN Economic Community 2015 (pp. 547-580). Fakultas Ekonomi dan Bisnis Universitas Kristen Satya Wacana.

Ikatan Akuntan Indonesia (IAI). (2009). Standar akuntansi keuangan entitas tanpa akuntabilitas publik. Dewan Standar Akuntansi Keuangan Ikatan Akuntan Indonesia.

Keputusan Menteri Keuangan No. 40/KMK.06/2003 tentang Pendanaan Kredit Usaha Mikro dan Kecil. (2003). Indonesia. https://jdih.kemenkeu.go.id/fulltext/2003/40 kmk.06 2003kep.htm

Shonhadji, N., Aghe, L., \& Dwujito. (2017). Penerapan penyusunan laporan keuangan pada usaha kecil menengah berdasarkan SAK EMKM di Surabaya. Prosiding Seminar Nasional Hasil Pengabdian Masyarakat: Vol 1(2) (pp. 130-136). http://senias.uim.ac.id/index.php/senias_2017/article/view/32 
Suhairi. (2004). Personality, accounting knowledge, accounting information usage and performance: a research on entrepreneurship of Indonesia Medium Enterprise [Disertasi, Universiti Sains Malaysia].

Wahyuningsih, E. D., Setiawati, I., \& Prasojo, T. A. (2017). Pemberdayaan pelaku usaha mikro dengan memberikan pelatihan pembukuan sederhana di Desa Bangunrejo Kecamatan Patebon Kabupaten Kendal. Prosiding Seminar Nasional Hasil-Hasil Penelitian dan Pengabdian Masyarakat: Implementasi Penelitian dan Pengabdian Masyarakat Untuk Peningkatan Kekayaan Intelektual (pp. 491-495).

https://jurnal.unimus.ac.id/index.php/psn12012010/article/view/2910 